\title{
Dejavniki, ki vplivajo na lokacijo manjših in srednje velikih podjetij v predmestju: primer metropolitanskega območja mest Gdansk, Gdynia in Sopot
}

Zaradi pomembne vloge manjših in srednje velikih podjetij (MSP) v evropskem gospodarstvu je ključno ustrezno poznavanje različnih dejavnikov, ki vplivajo na izbiro njihove lokacije. Kljub temu je v teoretičnih in empiričnih raziskavah industrijskih lokacij in urbanističnega načrtovanja velikost podjetij pogosto spregledana. $\mathrm{V}$ članku avtorji proučujejo kraj stalnega prebivališča kot dejavnik, ki spodbuja razvoj MSP v predmestjih. To smer razvoja potrjuje tudi multidisciplinarna raziskava, ki so jo izvedli na metropolitanskem območju mest Gdansk, Gdynia in Sopot. Dejavnike, ki vplivajo na lokacijo MSP na predmestnih območjih, so določili z anketo, ki so jo izvedli v 251 podjetjih v 7 občinah z najvišjo stopnjo suburba- nizacije na proučevanem metropolitanskem območju. Raziskava je potrdila, da je za občine, v katerih potekajo najintenzivnejši procesi suburbanizacije, značilna višja stopnja poslovne dejavnosti. Lastniki podjetij odločitve o lokaciji podjetja večinoma sprejemajo v skladu z načeli vedenjske teorije. To pomeni, da pri svojih odločitvah pogosteje upoštevajo osebne dejavnike kot stroške ali povpraševanje. Zanje so najpomembnejši dejavniki življenjske razmere, kakovost javnega prostora, izobrazba in zdravstvo.

Ključne besede: podjetništvo, MSP, predmestja, regionalni razvoj, suburbanizacija, Poljska 


\section{Uvod}

Manjša in srednje velika podjetja (MSP) imajo ključno vlogo $\mathrm{v}$ nacionalnih gospodarstvih, saj so gonilna sila podjetnišstva, razvoja, inovacij in konkurenčnosti. Gre za sektor, ki je motor regionalnega razvoja in blaginje. Pri določanju prostorske lokacije je pomembno, da lokalne oblasti in urbanisti dobro poznajo različne dejavnike, ki vplivajo na izbiro posameznih lokacij. Lokacija podjetja vpliva na njegovo delovanje, razvoj ter sposobnost ustvarjanja in ohranjanja konkurenčne prednosti (Porter, 2000). Zato se lokalne, regionalne in državne ustanove ter raziskovalci osredotočajo na iskanje in proučevanje dejavnikov, ki vplivajo na to, kako podjetja izbirajo lokacijo za svoje poslovanje. Kljub temu je v teoretičnih in empiričnih raziskavah industrijskih lokacij in urbanističnega načrtovanja njihova velikost pogosto spregledana, ne upoštevajo pa je niti tradicionalne niti neoklasične lokacijske teorije. Pregled empiričnih raziskav lokacijskih vzorcev MSP kaže, da je na tem področju še vedno precejšnja vrzel, zlasti v zvezi z Vzhodno Evropo. Kar je bil glavni razlog za to raziskavo. Njen glavni cilj je pridobiti boljši vpogled v dejavnike, ki odločilno vplivajo na izbiro lokacije MSP.

Razvoj sektorja MSP in sočasno nenačrtno širjenje mest na Poljskem je avtorje spodbudil k proučevanju tega, zakaj MSP za opravljanje dejavnosti izberejo lokacijo v predmestjih. Za poljska predmestja sta značilni velika razdrobljenost in visoka stopnja podjetništva v sektorju MSP (Martyniuk-Pęczek in Pęczek, v tisku). To je posledica družbeno-ekonomskih sprememb, ki so se v državi dogajale po letu 1989. Najbolj dinamične so bile prav v predmestjih. Na močno in nenehno rast teh območij po eni strani vplivajo hiter razvoj MSP, po drugi pa »ameriški slog življenja « in zahodnoevropski liberalizem, ki je veliko prispeval k pospešenemu nenačrtnemu širjenju mest na Poljskem. Zaradi medsebojnega vpliva teh dveh pojavov (razvoja MSP in suburbanizacije) se je tu razvila posebna urbana oblika predmestij.

Avtorji so raziskavo razdelili na prostorski in ekonomski del. $\mathrm{V}$ prostorskem delu so izbrali predmestne občine na metropolitanskem območju mest Gdansk, Gdynia in Sopot, kjer poteka najintenzivnejša suburbanizacija, in določili vpliv MSP na prostorsko kakovost izbranih predmestij. V ekonomskem delu so nato določili občine z največjo gostoto MSP in dejavnike, ki vplivajo na izbiro lokacije MSP.

$\mathrm{V}$ naslednjem poglavju je na kratko predstavljena empirična literatura $s$ tematiko izbiranja lokacije podjetij in obravnavana vloga velikosti podjetja. Nato avtorji predstavijo rezultate statističnih testov, opravljenih na vzorcu $251 \mathrm{MSP}$, ki so v predmestjih proučevanega metropolitanskega območja. Da bi potrdili rezultate statističnih testov, avtorji predstavijo tudi rezultate prostorske analize, v zadnjem poglavju pa povzamejo glavne ugotovitve.

\section{Lokacijski dejavniki MSP: pregled literature}

Pri iskanju kraja za opravljanje poslovnih dejavnosti vsako podjetje izbere lokacijo, ki najbolj ustreza njegovim potrebam. S prednostmi, kot so večja proizvodna zmogljivost, večji dobiček, širjenje poslovne dejavnosti, boljše storitve za stranke, povečanje delničarskega premoženja in nižji stroški, lahko primerna lokacija močno izboljša tržno konkurenčnost podjetja (Mazzarol in Choo, 2003). Hkrati pa lahko neprimerna lokacija negativno vpliva na podjetje. Z vprašanjem določanja in analiziranja lokacijskih dejavnikov podjetij so se ukvarjale že prve lokacijske teorije, ki so se sprva osredotočale na zmanjšanje stroškov (Thunen, 1826; Launhardt, 1882; Predöhl, 1928; Weber, 1929), nato pa tudi na analizo trga in povečanje dobička (Palander, 1935; Lösch, 1940; Hoover, 1948; Isard, 1956). V 2. polovici 20. stoletja je bil uveden vedenjski pristop (Pred, 1967), pri katerem je pri razlagi tega, kako nekdo izbere lokacijo, upoštevan obstoj odločevalca, čigar vedenje zaznamuje omejena racionalnost. Trenutno na izbiro lokacije podjetja najbolj vplivajo dejavniki, povezani s tehnološkim in družbenim razvojem (Van Noort in Reijmer, 1999), vendar ne moremo določiti univerzalnega izbora dejavnikov, ki vplivajo na odločitve o lokaciji podjetja. Lahko upoštevamo tudi do sto tovrstnih dejavnikov, zares pomembnih pa jih je le nekaj (Vlachou in Iakovidou, 2015). Pregled literature kaže, da lahko lokacijske dejavnike različno razvrstimo in razdelimo. Shelley M. Kimelberg in Elizabeth Williams (2013) ter Charisia Vlachou in Olga Iakovidou (2015) ugotavljajo, da lahko raziskave, ki se ukvarjajo z določanjem in razlago tovrstnih dejavnikov, razdelimo na tri kategorije: a) raziskave, ki merijo vpliv točno določenega dejavnika ali več dejavnikov na odločitve o lokaciji podjetja; b) raziskave, ki razlagajo izbiro lokacije za točno določeno panogo ali podjetje $s$ točno določenimi lastnostmi, in c) raziskave, ki proučujejo lokacijske dejavnike, ki vplivajo na podjetja na točno določenem območju. Peter Lloyd in Peter E. Dicken (1990) ter Jouke van Dijk in Piet Pellenbarg (2000) denimo razlikujejo med notranjimi dejavniki (kakovost upravljanja, organizacijski cilji, lastniška struktura, zaposlovanje in dobiček), lokacijskimi dejavniki (velikost parcele, velikost prostora za možno širitev ter oddaljenost strank in dobaviteljev) in zunanjimi dejavniki (naravne razmere, pravni položaj, vladna politika in regionalna gospodarska struktura).

Tovrstne dejavnike lahko razdelimo tudi na »mehke « in »trde «. Mehki dejavniki se nanašajo na neizmerljive in pogosto subjektivne vidike odločanja, kot so odnos lokalnih 
oblasti, gospodarske značilnosti lokacije, družbeno ozračje, kakovost življenja, življenjski standard in lokalna kulturna ponudba. Sem spadata tudi kakovost javnega prostora in urejenost prostora. Trdi dejavniki pa so pogosto izmerljivi z vidika stroškov in vključujejo oskrbo $s$ proizvodnimi in pisarniškimi prostori, bližino trgov, nabavo energije, bližino dobaviteljev in poslovnih partnerjev, prevoz, oskrbo s kvalificirano delovno silo, regionalno davčno politiko, politiko subvencij, obstoj raziskovalnih in znanstvenih ustanov ter kakovost in prilagodljivost lokalne uprave (Van Noort in Reijmer, 1999; Leśniewski, 2012). Edwin Van Noort in Inge Reijmer sta lokacijske dejavnike razdelila na tri skupine: dejavnike, povezane s poslovnim okoljem (dobavitelji, stranke in najuspešnejša podjetja), dejavnike, povezane s fizičnim okoljem (dostop z avtom in javnim prevozom, kakovost in podoba poslovne lokacije, velikost lokacije in njena okolica), in dejavnike, povezane z institucionalnim okoljem (spodbude in okoljska zakonodaja; Risselada in Schutjens, 2012). V novejši raziskavi so Yancy Vaillant idr. (2012) lokacijske dejavnike razdelili na tri skupine glede na razloge za izbiro lokacije: infrastrukturne in gospodarske razloge, osebne razloge in razloge, povezane z lokacijo.

Velikost podjetja vsekakor vpliva na pomen posameznega lokacijskega dejavnika, vendar v lokacijskih teorijah in številnih empiričnih raziskavah kljub temu ni upoštevana. Poleg tega se je večina raziskav osredotočala na odločevalske procese v velikih podjetjih, le malo pozornosti pa je bilo namenjene temu, kako tovrstne odločitve sprejemajo MSP. Mikropodjetja ter manjša in srednje velika podjetja se razlikujejo od velikih podjetij in z vidika odločanja o lokaciji se te razlike nanašajo zlasti na odločevalca, možnost pridobivanja informacij o točno določeni lokaciji in finančne vire. $Z a$ zdaj še ni ustreznega teoretičnega okvira, $s$ katerim bi lahko razložili, zakaj vedenje manjših podjetij ne kaže vedenja velikih. Nekaj empiričnih primerov lahko najdemo v raziskavah, ki so jih izvedli Barry Moore idr. (1991), Pauline Sullivan idr. (1998), Van Noort in Reijmer (1999), Josep-Maria Arauzo-Carod in Miguel Manjon-Antolin (2004), Maria Teresa Costa idr. (2004) ter Michał Flieger (2013). V vseevropski raziskavi, ki so jo opravili Moore idr. (1991), se je za najpomembnejši dejavnik, ki je vplival na lokacijske odločitve velikih in srednje velikih podjetij, izkazala razpoložljivost pomoči za regionalni razvoj, pri manjših pa je bil najpomembnejši dejavnik dostop do strank (Moore idr., 1991). Empirične raziskave, opravljene v katalonskih občinah, pa so pokazale, da na odločitve velikih podjetij vplivajo objektivnejši razlogi, manjša pa usmerjajo predvsem podjetnikove preference. $V$ praksi so možnosti, ki jih imajo na voljo manjša podjetja, pogosto omejene na najbližje geografsko območje (Arauzo-Carod in Manjon-Antolin, 2004). Na Nizozemskem pri izbiri lokacije MSP ne gre za strateško odločitev (v primerjavi z izbiro lokacije velikih podjetij; Risselada in Schutjens, 2012), saj je običajno le kratkoročna. MSP pri izbiri upoštevajo le omejeno število različnih dejavnikov. To le redko velja tudi za velika podjetja. Poleg tega so bili na Nizozemskem »mehki« dejavniki (ugled in karizma) razmeroma pomembnejši za večja podjetja kot MSP (Risselada in Schutjens, 2012). Sullivan idr. (1998) so ugotovili, da v primerjavi z MSP velika podjetja dajejo največji poudarek fizični infrastrukturi oziroma dostopu do železnice, letališč in pristanišč. Poleg tega pripisujejo precej večji pomen razpoložljivosti delovne sile, ugodnim posojilom, javnemu prevozu in poceni lokalni delovni sili. Chyi-lyi (Kathleen) Liang idr. (2001) navajajo, da so lokacijske odločitve manjših podjetij pogosto povezane z osebnimi dejavniki, kot so okolje (kakovost življenja), stalno prebivališče (želijo ostati doma), dostop do kapitala, lokalnih in regionalnih strank ter razpoložljivost ustrezne infrastrukture. Raziskava avstralskih MSP, ki sta jo izvedla Valerie Kupke in John Pearce (1998), je pokazala, da sta bila najpomembnejša dejavnika, ki sta vplivala na izbiro industrijske lokacije, bližina poslovnega središča mesta in neposreden dostop do glavnih cest.

Večina raziskav dejavnikov, ki vplivajo na izbiro lokacije poljskih podjetij, se osredotoča na določanje notranjih in zunanjih dejavnikov ter lokalnih prednosti izbranega območja, manj pa analizirajo njihov pomen glede na velikost podjetja (Budner, 2004; Godlewska, 2005; Płaziak in Szymańska, 2014). Med poljskimi raziskovalci so velikost podjetij proučevali Małgorzata Poniatowska-Jaksch (1997), Flieger (2013), Mariola Chrzanowska in Nina Drejerska (2015) ter Hanna Godlewska-Majkowska (2016). Flieger (2013) ugotovlja, da so za MSP pomembni le dejavniki, povezani s stroški (lokalne dajatve, najemnina, stroški delovne sile, možnosti pridobivanja sredstev za podporo poslovanju), za velika podjetja pa so pomembni dejavniki, povezani s tehnološko infrastrukturo, bližino avtoceste, stroški delovne sile in možnostjo sodelovanja z lokalnimi podjetji. Najpomembnejši dejavnik v raziskavi, ki jo je opravila Poniatowska-Jaksch (1997), je bilo lastništvo objektov. Chrzanowska in Drejerska (2015) pa omenjata dva lokacijska dejavnika: bližino mesta in priložnosti na lokalnem trgu.

\section{Metodologija in rezultati 3.1 Metodologija}

Raziskava suburbanizacije in razvoja MSP je bila razdeljena na dva dela. Cilj prostorskega dela raziskave je bil določiti občine na metropolitanskem območju mest Gdansk, Gdynia in Sopot $\mathrm{z}$ najvišjo stopnjo suburbanizacije in vrsto pozidave posameznih parcel, cilj ekonomskega dela pa je bil izbrati občine oziroma mesta z najvišjo koncentracijo MSP in določiti dejavnike, ki vplivajo na lokacijske odločitve tamkajšnjih MSP. Proučevano območje je pomemben del funkcijske in prostorske zgradbe Pomorjanskega vojvodstva ter najpomembnejše gospodarsko in družbeno središče na območju južnega Baltika. Med polj- 


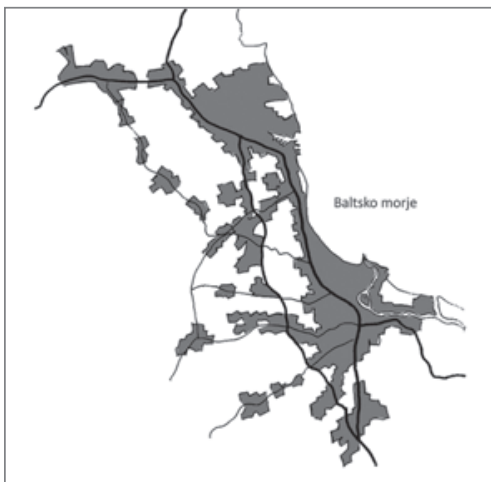

Prostorska zgradba metropolitanskega območja

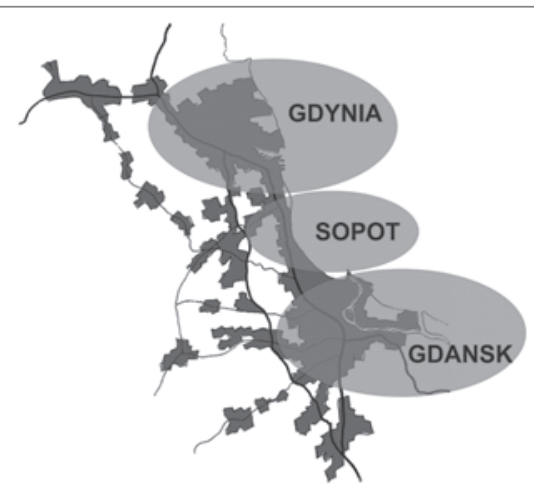

Osrednja mesta

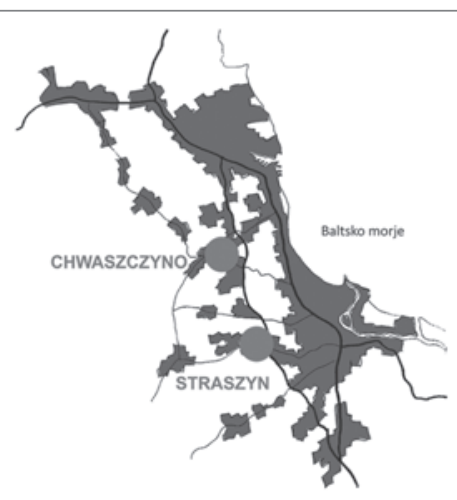

Predmestni podjetniški centri

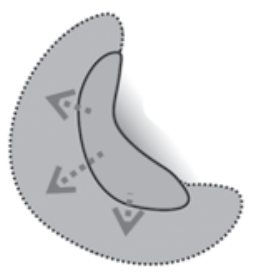

1. korak: Analiza migracij in indeksa gradbene dejavnosti

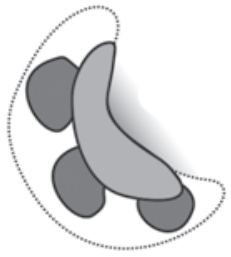

Ugotovitve Občine z najvišjo stopnjo suburbanizacije

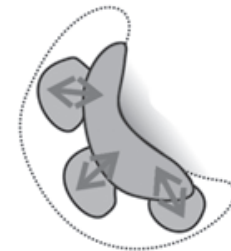

2. korak:

Intenzivnost gospodarske kvocientom (LK)

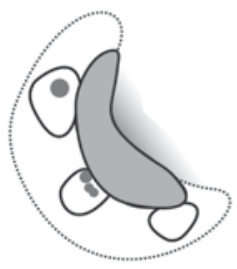

Ugotovitve

Obcine z najvišjo koncentracijo MSP glede na koncentracijo prebivalstva na izbranem območju = predmestni podjetniški centri

Slika 1: Določanje podjetniških centrov v predmestjih na podlagi prostorske zgradbe metropolitanskega območja (ilustracija: Justyna Martyniuk-Peczek)

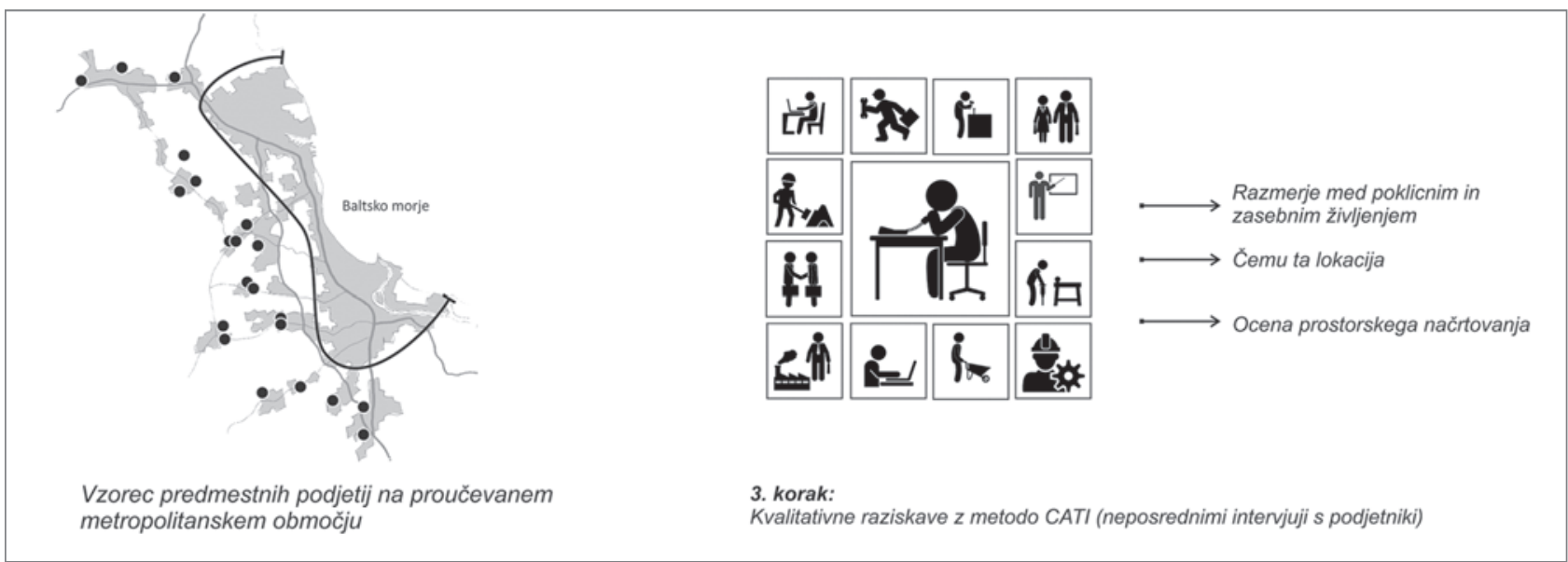

Slika 2: Koncept kvalitativne raziskave v izbranih predmestnih občinah obravnavanega metropolitanskega območja (ilustracija: Justyna Martyniuk-Peczek)

skimi vojvodstvi je Pomorjansko vojvodstvo na drugem mestu glede stopnje razvoja podjetništva. ${ }^{[1]} \mathrm{V}$ njem je registriranih približno $7 \%$ poljskih MSP.

Avtorji so stopnjo suburbanizacije določili na podlagi analize migracij v letih 2003-2012 ter indeksa gradbene dejavnosti v letih 2008-2012. Intenzivnost gospodarske dejavnosti so izmerili z lokacijskim kvocientom (LK), s katerim merimo razmerje med koncentracijo določene značilnosti na določenem območju (v odstotkih značilnosti na splošno) in stopnjo koncentracije prebivalstva na tem območju (v odstotkih skupnega prebivalstva).
Da bi določili lokacijske dejavnike MSP, so leta 2015 izvedli raziskavo med 251 podjetji v predmestjih na območju obravnavanega metropolitanskega območja, ${ }^{[2]}$ kjer poteka najmočnejša suburbanizacija in ki imajo največjo koncentracijo MSP. Uporabili so metodo računalniško podprtega telefonskega anketiranja (CATI). Slika 2 prikazuje koncept te kvalitativne raziskave, ki je temeljila na neposrednih intervjujih s podjetniki, oziroma zgradbo uporabljenega vprašalnika, razdeljenega na tri dele (prvi se je nanašal na razmerje med poklicnim in zasebnim življenjem, drugi na lokacijo in tretji na vprašanja, povezana $z$ oceno prostorskega načrtovanja). Za vzorčenje so 


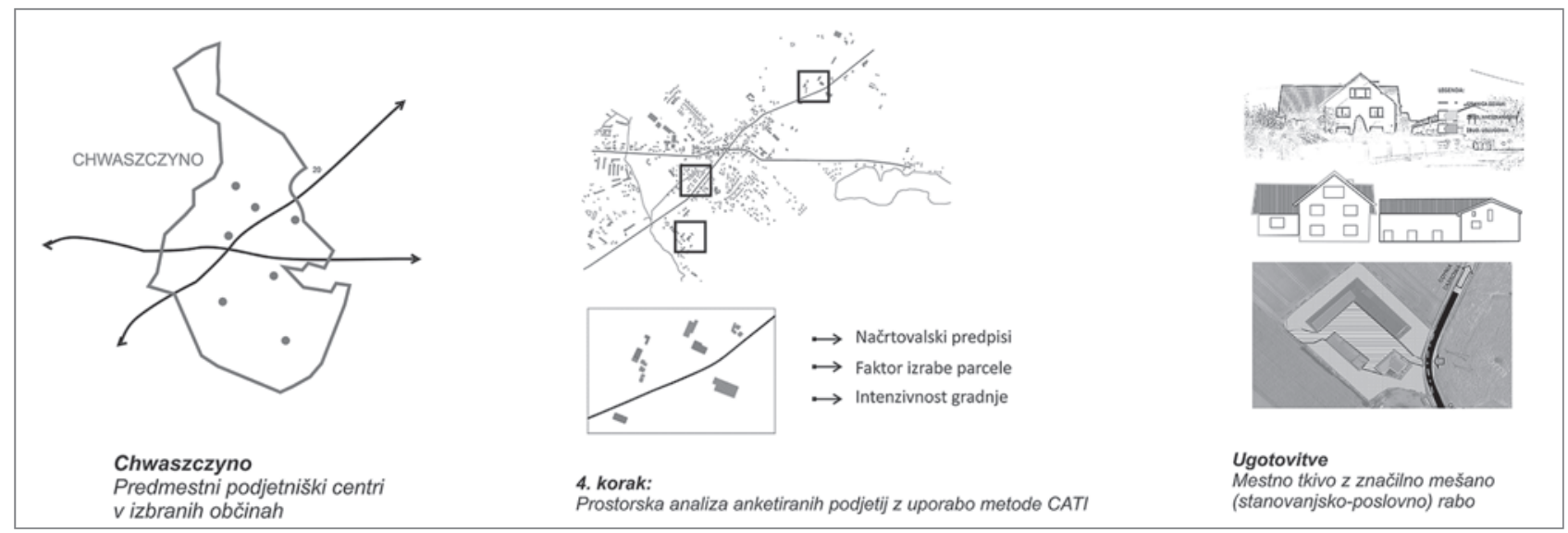

Slika 3: Analiza urbanističnih in arhitekturnih oblik izbranih poslovnih objektov v treh korakih (ilustracija: Justyna Martyniuk-Peczek)

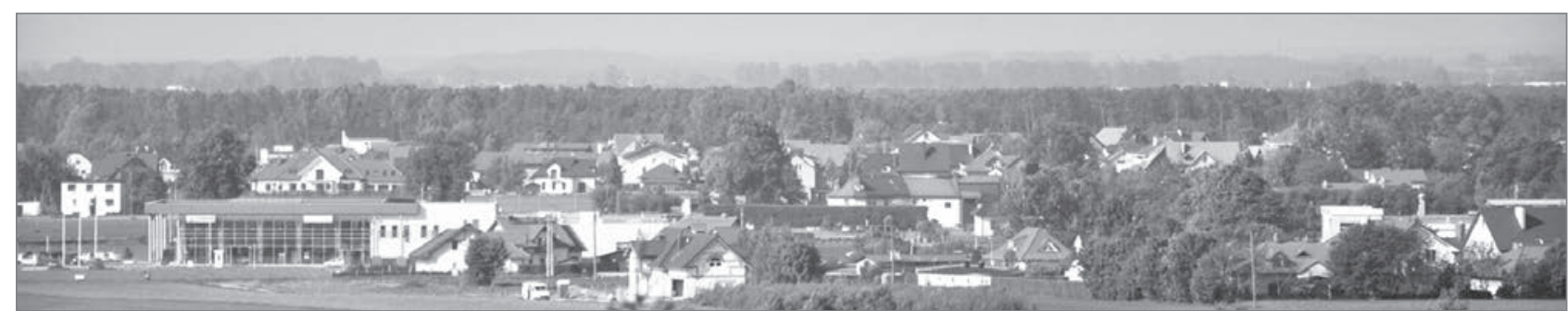

Slika 4: Stanovanjsko tkivo s storitvenimi objekti v mestu Hvaščino (foto: Grzegorz Peczek)

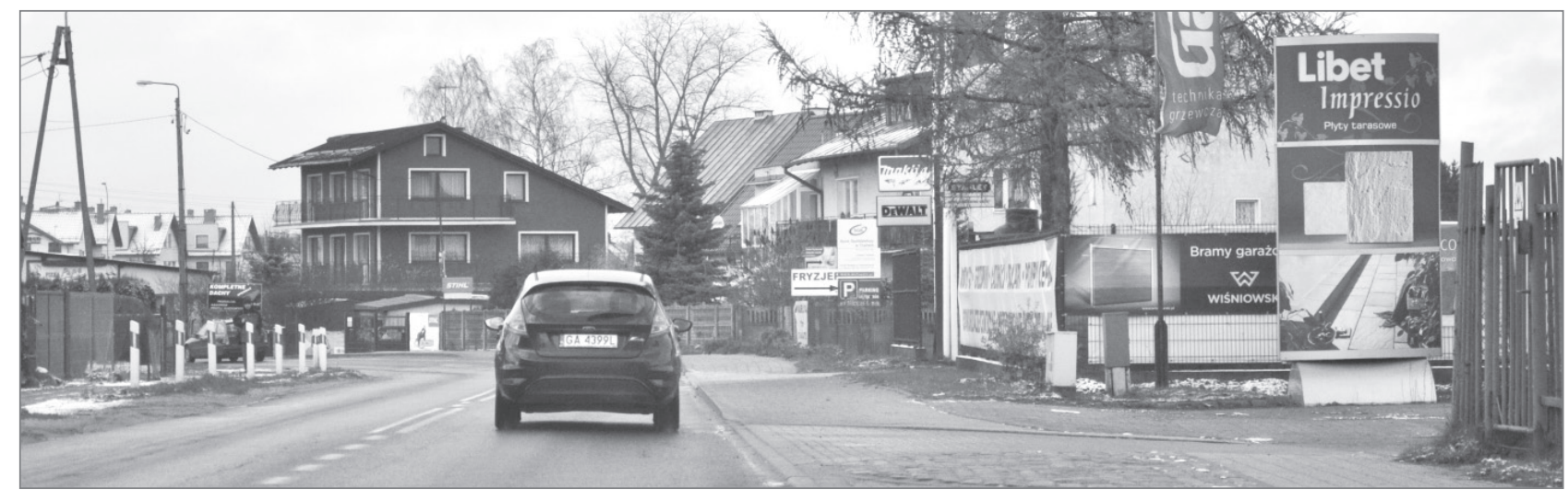

Slika 5: Mesto Hvaščino in oglasne table na glavni ulici (foto: Grzegorz Peczek)

uporabili matične številke podjetij (REGON), končni vzorec pa oblikovali na podlagi podatkovne zbirke 3.500 podjetij iz izbranih predmestij. Uporabili so metodo namerno-naključnega vzorčenja (ang. purposive random sampling) in za vsak primer določili še $10 \%$ rezervnih podjetij. Podjetja v vzorcu so bila razvrščena glede na občine, mesta in velikost. Proučevani poslovni subjekti so vključevali:

- podjetja z 2 do 9 zaposlenimi (mikropodjetja, vštevši samozaposlene), ki so predstavljala 83,3 \% podjetij v vzorcu;

- podjetja z 10 do 49 zaposlenimi (manjša podjetja), ki so predstavljala $14,7 \%$ podjetij v vzorcu;

- podjetja s 50 do 249 zaposlenimi (srednje velika podjetja), ki so predstavljala $2 \%$ podjetij.
Skupni rezultati vprašalnika kažejo rezultate mikropodjetij in delno tudi manjših podjetij. To je posledica tega, da so mikropodjetja in manjša podjetja pomenila $98 \%$ vseh podjetij $\mathrm{v}$ proučevanem vzorcu. Struktura vzorca je podobna strukturi podjetij v vsej državi, kjer mikroodjetja in manjša podjetja pomenijo $98,9 \%$ vseh poslovnih subjektov. ${ }^{[3]} \mathrm{V}$ vzorcu je bilo največ trgovskih $(26,4 \%)$, industrijskih $(18,3 \%)$ in gradbenih podjetij (11,2\%). Merili so tudi moč oziroma stopnjo korelacije med značilnostmi podjetja in najpomembnejšimi lokacijskimi dejavniki. Proučevali so korelacije med temi značilnostmi: velikostjo podjetja (mikropodjetja, manjša ali srednje velika podjetja), starostjo podjetja (1 do 5 let, 6 do 15 let, več kot 15 let), vrsto poslovne dejavnosti (proizvodnja, trgovina, storitve), vrsto podjetja (družinsko ali nedružinsko podjetje) in 
spremenljivkami, ki kažejo, ali sta stalno prebivalǐ̌če in njegova bližina pomembno vplivala na izbiro lokacije podjetja. Uporabili so test hi-kvadrat, pri katerem so frekvence, ugotovljene v vzorcu, primerjali s pričakovanimi frekvencami ob domnevi, da sta spremenljivki neodvisni. Za merjenje stopnje korelacije so uporabili Cramerjev V-koeficient in Yulov fi-koeficient, katerih vrednost se giblje med 0 in 1 . Vrednosti blizu 0 kažejo šibko korelacijo, vrednosti blizu 1 pa nakazujejo močno korelacijo.

$\mathrm{Na}$ koncu so avtorji želeli izsledke kvalitativne raziskave primerjati z realnim stanjem, zato so izbrane parcele proučili tudi z urbanističnega in arhitekturnega vidika (slika 3). Zanimalo jih je, ali tudi za posamezne parcele veljajo določena načela glede izbiranja lokacije MSP.

Za vsako proučevano parcelo so opravili enako prostorsko analizo, pri kateri so upoštevali te tehnične urbanistične parametre: površina parcele, pozidana površina, višina stavbe (število nadstropij nad tlemi), velikost zelenih površin, faktor izrabe gradbene parcele in intenzivnost gradnje. Nato so proučili še značilnosti objektov na parcelah, kjer so mikropodjetja ter manjša in srednje velika podjetja, pri čemer so analizirali tri glavne plasti: število objektov na parceli, obstoj stanovanjskega objekta in poslovno dejavnost v njem. Namen tega dela analize je bil določiti urbanistične in arhitekturne odvisnosti med stanovanjsko gradnjo in izvajanjem poslovne dejavnosti. Rezultati analize so predstavljeni v preglednici 4 . Sliki 4 in 5 prikazujeta podjetniško krajino, v kateri prevladuje gradnja nizke gostote (predvsem enodružinske hiše). Za te lokacije je značilno, da so na gosto posejane z oglasnimi tablami (slika 5).

Avtorji se zavedajo pomanjkljivosti raziskovalnih metod, ki so jih izbrali za ocenjevanje suburbanizacije in gospodarske dejavnosti, vendar gre za slabosti, na katere nimajo vpliva in so povezane predvsem $\mathrm{z}$ načinom zbiranja statističnih podatkov na Poljskem. Pri merjenju dinamike migracij je ena takih slabosti denimo dejstvo, da državljanom ni treba prijaviti spremembe naslova in da imajo lahko $\mathrm{v}$ lasti več domov, pri analizi gradbene dejavnosti pa se lahko pojavijo napake zaradi zamud pri prijavi dokončanih stavb. Slabost, povezana z analizo gospodarske dejavnosti, ki temelji na številu registriranih MSP, pa je razlog, da dejanski kraj opravljanja poslovne dejavnosti pogosto ni enak sedežu podjetja (tj. kraju registracije).

\subsection{Rezultati}

Na podlagi primerjave podatkov o neto migracijah in indeksa gradbene dejavnosti so avtorji določili sedem občin na proučevanem metropolitanskem območju, $\mathrm{v}$ katerih poteka najintenzivnejša suburbanizacija. Na podlagi lokacijskega kvocienta, $s$ katerimi so merili razmerje med stopnjo koncentracije MSP v posamezni občini in številom prebivalstva, so izbrali dve me- sti z največjo koncentracijo MSP (Hvaščino in Strašin), ki ju zato lahko obravnavamo kot podjetniška centra proučevanega metropolitanskega območja (Martyniuk idr., 2016). Rezultati kvalitativne raziskave, ki kažejo pogostost odgovorov v zvezi s tem, ali je posamezen dejavnik odločilno vplival na izbiro lokacije MSP, so predstavljeni v preglednici 1 . Statistično značilne povezave $(p<0,1)$ pa so prikazane $\mathrm{v}$ preglednici 2.

Raziskava je pokazala, da tri četrtine mikropodjetij $(79,3 \%)$ in skoraj polovica manjših podjetij (48,6\%) poslovno dejavnost opravlja v podjetnikovem kraju stalnega prebivališča oziroma v njegovi bližini. Razlogi za to so lahko pomanjkanje kapitala, poznavanje lokalnih tržnih priložnosti ter potreba po navezovanju osebnih stikov in oblikovanju mrež, ki so na voljo le v »domači « regiji. Avtorji niso našli drugih primerov empiričnih raziskav tovrstnih lokacijskih dejavnikov v Vzhodni Evropi, ki bi bile napisane $\mathrm{v}$ angleščini, zato njihovih ugotovitev ni mogoče kritično oceniti in povezati z izsledki drugih raziskovalcev s tega območja. Ugotovitev, da mikropodjetja in manjša podjetja svojo poslovno dejavnost opravljajo v kraju lastnikovega stalnega prebivališča, pa so predstavili in potrdili tudi raziskovalci drugje po svetu, recimo Rigoberto A. Lopez in Nona R. Henderson (1989), Liang idr. (2001), Tim Mazzarol in Stephen Choo (2003) ter Anne Risselada in Veronique Schutjens (2012). Stalno prebivališče se denimo ni izkazalo za odločilni lokacijski dejavnik v raziskavi, ki sta jo opravila Kupke in Pearce (1998). Res pa je, da sta raziskavo opravila $\mathrm{v}$ avstralskem mestu Adelaide, torej na precej drugačnem gospodarskem in političnem območju, kot je metropolitansko območje mest Gdansk, Gdynia in Sopot.

Izsledki poljskih raziskav, opravljenih na območju Velikopoljskega vojvodstva (Flieger, 2013) in Svetokriškega vojvodstva (Leśniewski, 2012), kažejo, da so stroški poslovne dejavnosti glavni dejavnik, ki vpliva na izbiro lokacije podjetja. Težko pa te izsledke primerjamo, saj raziskave, ki sta jih izvedla Leśniewski in Flieger, niso vključevale merila, kot je stalno prebivališčce.

Anketirani so kot drug pomemben dejavnik, ki vpliva na izbiro lokacije, navedli bližino osrednjih mest metropolitanskega območja (Gdansk, Sopot in Gdynia). Statistično značilne povezave, ki jih je pokazal test hi-kvadrat $(p<0,1)$, so navedene v preglednici 3. Ker se preǰsnje raziskave, v katerih so avtorji ugotovili povezave med lokacijskimi dejavniki in točno določenimi območji, večinoma nanašajo na mestna (Karakaya in Canal, 1998; Cohen, 2000; Prat in Marcen, 2006) ali podeželska območja (Michelacci in Silva, 2007; Yu in Artz, 2009; Vaillant idr., 2012), ne na predmestja, teh izsledkov ne moremo kritično analizirati in jih povezati z ugotovitvami mednarodnih raziskav. Predmestna območja so z vidika lokacijskih dejavnikov MSP proučevale Poniatowska-Jaksch (1997) ter 
Preglednica 1: Dejavniki, ki vplivajo na izbiro lokacije MSP v predmestjih metropolitanskega območja mest Gdansk, Gdynia in Sopot z najvišjo stopnjo suburbanizacije

\begin{tabular}{|c|c|c|c|c|}
\hline Dejavnik & Skupni rezultat (\%) & Mikropodjetja (\%) & Manjša podjetja (\%) & Srednje velika podjetja (\%) \\
\hline stalno prebivališče & 42,8 & 47,1 & 24,3 & 0,0 \\
\hline bližina osrednjega mesta & 32,4 & 33,7 & 29,7 & 0,0 \\
\hline bližina stalnega prebivališča & 30,4 & 32,2 & 24,3 & 0,0 \\
\hline $\begin{array}{l}\text { ugodne } \\
\text { prometne razmere }\end{array}$ & 24,4 & 25,5 & 21,6 & 0,0 \\
\hline $\begin{array}{l}\text { osebni razlogi } \\
\text { (družina, varstvo otrok) }\end{array}$ & 19,6 & 21,6 & 10,8 & 0,0 \\
\hline bližina glavne stranke & 14,0 & 16,3 & 2,7 & 0,0 \\
\hline infrastruktura & 14,0 & 15,9 & 5,4 & 0,0 \\
\hline povpraševanje & 14,0 & 15,9 & 5,4 & 0,0 \\
\hline nizki investicijski stroški & 10,0 & 9,6 & 10,8 & 20,0 \\
\hline nizke cene zemljišč & 8,0 & 8,2 & 8,1 & 0,0 \\
\hline naravne razmere & 6,0 & 7,2 & 0,0 & 0,0 \\
\hline nizki prevozni stroški & 5,6 & 6,3 & 2,7 & 0,0 \\
\hline poceni delovna sila & 4,8 & 4,8 & 5,4 & 0,0 \\
\hline predhodna analiza lokacije & 4,8 & 5,3 & 2,7 & 0,0 \\
\hline dostop do surovin & 2,8 & 3,4 & 0,0 & 0,0 \\
\hline $\begin{array}{l}\text { razpoložljive ugodnosti } \\
\text { za podjetnike }\end{array}$ & 2,0 & 2,4 & 0,0 & 0,0 \\
\hline drugo & 23,2 & 19,2 & 37,8 & 80,0 \\
\hline
\end{tabular}

Vir: Lastni izračuni na podlagi vprašalnika

Preglednica 2: Povezave med značilnostmi podjetja ter stalnim prebivališčem in bližino stalnega prebivališča

\begin{tabular}{|c|c|}
\hline \multicolumn{2}{|c|}{$\begin{array}{l}\text { 1. Velikost podjetja in stalno prebivališče kot dejavnik, ki vpliva na izbiro lokacije } \\
p=0,019 \text {, Cramerjev V-koeficient }=0,20\end{array}$} \\
\hline Velikost podjetja & Odstotek podjetij v vzorcu, ki so stalno prebivališče navedla kot dejavnik, ki vpliva na izbiro lokacije \\
\hline mikro & $47 \%$ \\
\hline manjše & $24 \%$ \\
\hline srednje veliko & $0 \%$ \\
\hline \multicolumn{2}{|c|}{ 2. Vrsta podjetja in stalno prebivališče kot dejavnik, ki vpliva na izbiro lokacije } \\
\hline \multicolumn{2}{|c|}{$p=0,0001$, Yulov fi-koeficient $=0,25$} \\
\hline Vrsta podjetja & Odstotek podjetij v vzorcu, ki so stalno prebivališče navedla kot dejavnik, ki vpliva na izbiro lokacije \\
\hline družinsko podjetje & $58 \%$ \\
\hline nedružinsko podjetje & $32 \%$ \\
\hline \multicolumn{2}{|c|}{ 3. Vrsta podjetja in bližina stalnega prebivališča kot dejavnik, ki vpliva na izbor lokacije } \\
\hline \multicolumn{2}{|c|}{$p=0,059$, Yulov fi-koeficient $=0,12$} \\
\hline Vrsta podjetja & Odstotek podjetij v vzorcu, ki so stalno prebivališče navedla kot dejavnik, ki vpliva na izbiro lokacije \\
\hline družinsko podjetje & $37 \%$ \\
\hline nedružinsko podjetje & $26 \%$ \\
\hline
\end{tabular}

Vir: Lastni izračuni na podlagi vprašalnika 


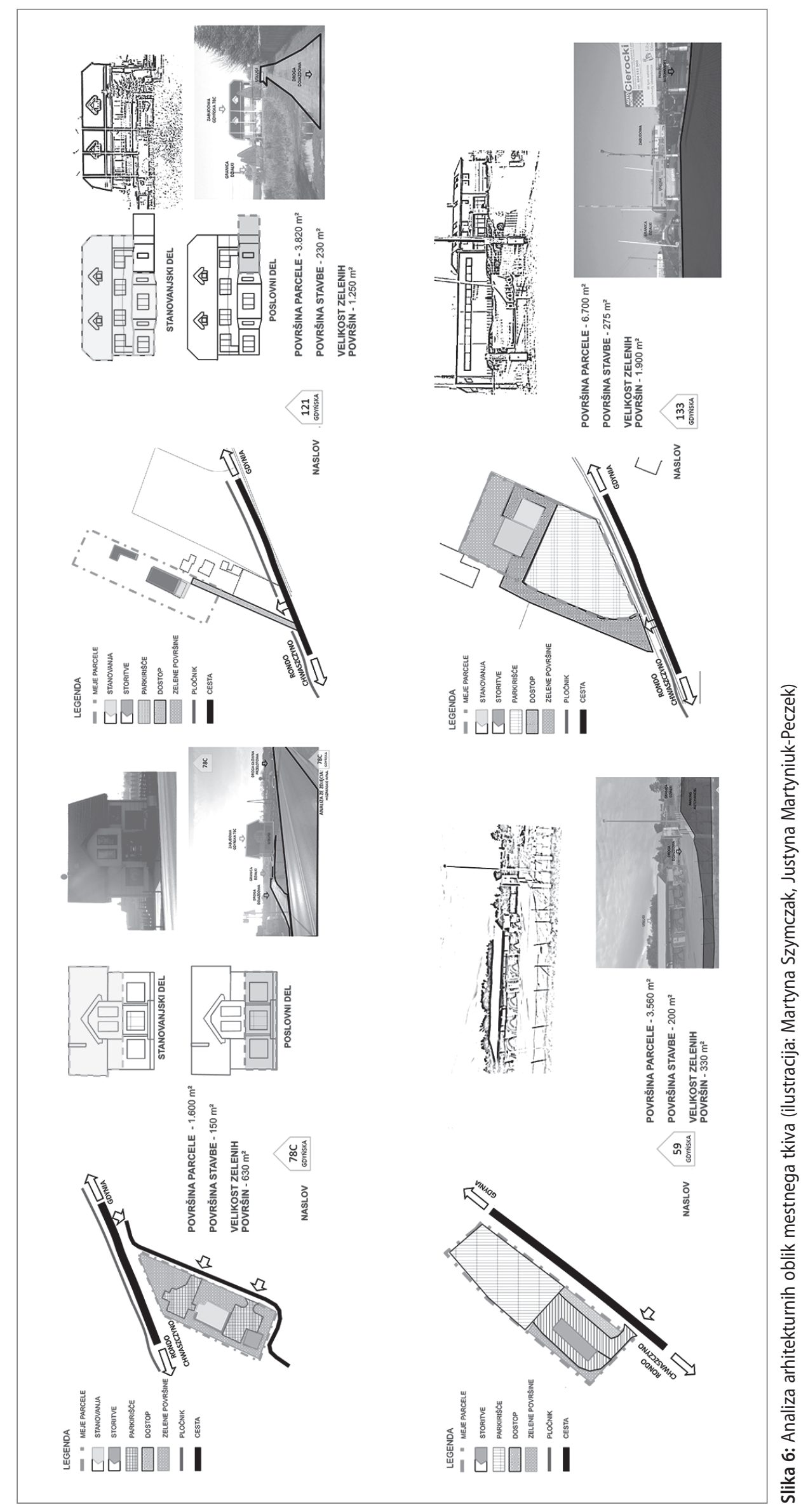


Preglednica 3: Povezave med značilnostmi podjetja in bližino osrednjih mest

\begin{tabular}{|c|c|}
\hline $\begin{array}{l}\text { 1. Vrsta poslovne dejavnos } \\
p=0,037 \text {, Cramerjev V-k }\end{array}$ & $\begin{array}{l}\text { bližina osrednjih mest kot dejavnik, ki vpliva na izbiro lokacije } \\
\text { cient }=0,16\end{array}$ \\
\hline Vrsta poslovne dejavnosti & Odstotek podjetij v vzorcu, ki so bližino osrednjih mest navedla kot dejavnik, ki vpliva na izbiro lokacije \\
\hline proizvodnja & $35 \%$ \\
\hline trgovina & $40 \%$ \\
\hline storitve & $22 \%$ \\
\hline 2. Vrsta podjetja in bližina & dnjih mest kot dejavnik, ki vpliva na izbiro lokacije \\
\hline$p=0,003$, Yulov fi-koefic & $=0,19$ \\
\hline Vrsta podjetja & Odstotek podjetij v vzorcu, ki so bližino osrednjih mest navedla kot dejavnik, ki vpliva na izbiro lokacije \\
\hline družinsko podjetje & $43 \%$ \\
\hline nedružinsko podjetje & $25 \%$ \\
\hline
\end{tabular}

Vir: Lastni izračuni na podlagi vprašalnika

Preglednica 4: Izbrani parametri in rezultati za mesti Hvaščino in Strašin

\begin{tabular}{|c|c|c|c|c|c|c|}
\hline Mesto & Ulični naslov & Velikost parcele $\left(\mathrm{m}^{2}\right)$ & $\begin{array}{l}\text { Odstotek } \\
\text { stavb }\end{array}$ & $\begin{array}{l}\text { Število } \\
\text { stavb }\end{array}$ & $\begin{array}{l}\text { Stanovanjske } \\
\text { stavbe }\end{array}$ & $\begin{array}{l}\text { Poslovna dejavnost v } \\
\text { stanovanjski stavbi }\end{array}$ \\
\hline \multirow{18}{*}{ Hvaščino } & Waska 21 & 4.300 & 13 & 2 & 0 & 0 \\
\hline & Polna 9 & 9.130 & 19 & 3 & 1 & 0 \\
\hline & Ogrodowa 3 & 1.130 & 18 & 1 & 1 & 1 \\
\hline & Oliwska 92 & 356 & 24 & 1 & 1 & 1 \\
\hline & Gdynska 78 & 4.200 & 14 & 3 & 1 & 0 \\
\hline & Gdynska 78C & 1.600 & 9 & 1 & 1 & 1 \\
\hline & Gdynska 94 & 1.630 & 9 & 1 & 0 & 0 \\
\hline & Gdynska 59 & 3.560 & 6 & 1 & 0 & 0 \\
\hline & Waska 23 & 1.640 & 23 & 1 & 1 & 0 \\
\hline & Jarzebinowa 5 & 865 & 26 & 1 & 1 & 1 \\
\hline & Swierkowa 72 & 1.200 & 14 & 1 & 1 & 1 \\
\hline & Sienkiewicza Henryka 2 & 830 & 18 & 1 & 1 & 1 \\
\hline & Norwida Cypriana Kamila 14 & 790 & 18 & 1 & 1 & 1 \\
\hline & Sychty Bernarda 18 & 630 & 27 & 2 & 1 & 0 \\
\hline & Majkowskiego 2 & 815 & 29 & 2 & 1 & 1 \\
\hline & Gdynska 133 & 6.270 & 4 & 1 & 0 & 0 \\
\hline & Gdynska 121 & 3.820 & 22 & 3 & 1 & 0 \\
\hline & Kaszubska Droga 5 & 1.320 & 10 & 2 & 1 & 1 \\
\hline \multirow{15}{*}{ Strašin } & Rozana 19 & 512 & 25 & 2 & 1 & 1 \\
\hline & Meblowa 10 & 3.500 & 46 & 3 & 0 & 0 \\
\hline & Liliowa 4 & 605 & 13 & 1 & 1 & 1 \\
\hline & Swierkowa 27 & 675 & 16 & 1 & 1 & 1 \\
\hline & Mlynska 7 & 8.000 & 35 & 5 & 0 & 0 \\
\hline & Starogardzka $42-44$, stavba A & 4.730 & 36 & 2 & 0 & 0 \\
\hline & Teczowa 1 & 465 & 26 & 1 & 1 & 1 \\
\hline & Liliowa 5 & 850 & 22 & 2 & 1 & 1 \\
\hline & Szafirowa 11 & 1.200 & 13 & 1 & 1 & 1 \\
\hline & Starogardzka 38 & 1.130 & 27 & 1 & 0 & 0 \\
\hline & Spokojna 68 & 2.580 & 10 & 2 & 1 & 1 \\
\hline & Ogrodowa 19 & 600 & 18 & 1 & 1 & 1 \\
\hline & Objazdowa 5 & 3.445 & 18 & 2 & 0 & 0 \\
\hline & Starogardzka 22 & 705 & 23 & 1 & 1 & 1 \\
\hline & Spokojna 52 & 3.450 & 30 & 1 & 0 & 0 \\
\hline
\end{tabular}


Chrzanowska in Drejerska (2015). Obe raziskavi sta se osredotočali na predmestje Varšave. Tukaj predstavljeni rezultati v zvezi z bližino osrednjega mesta kot pomembnim lokacijskim dejavnikom se ujemajo z ugotovitvami za Varšavo.

Naslednji dejavnik, ki vpliva na izbiro lokacije MSP v predmestjih proučevanega metropolitanskega območja, so ugodne prometne razmere. Avtorji so ugotovili statistično pomembno povezavo med vrsto podjetja in tem, ali dober prometni sistem vpliva na izbiro lokacije podjetja $(p=0,021$, Yulov fi-koeficient $=0,15)$. Na splošno je $25,5 \%$ mikropodjetij in $21,6 \%$ manjših podjetij v vzorcu navedlo, da so ugodne prometne razmere vplivale na izbiro njihove lokacije. Vloga prometa ima v klasični lokacijski teoriji dolgo tradicijo. Ceste se pogosto navajajo kot najpomembnejša vrsta prometne infrastrukture. Čeprav je za podjetja razpoložljivost dobre prometne infrastrukture zelo pomemben dejavnik, le redko odločilno vpliva na izbiro lokacije. Ta ugotovitev se v zvezi z MSP ujema z izsledki Moora idr. (1991), da je infrastruktura razmeroma nepomemben lokacijski dejavnik. Sullivan idr. (1998) navajajo, da ima v primerjavi z velikimi podjetji v MSP infrastruktura manj pomembno vlogo. Do enakih ugotovitev je prišel tudi Flieger (2013), tu predstavljeni kvalitativni rezultati pa so podobni rezultatom prej omenjene poljske raziskave (Leśniewski, 2012).

Da bi potrdili ugotovitve ekonomskega dela raziskave, so avtorji opravili urbanistično analizo, pri kateri so določili vrste mestnega tkiva in jim pripisali značilnosti, ki se nanašajo na parametre njihove gradnje (slika 6). V zgornji vrstici slike 6 je prikazana prevladujoča vrsta stavb (značilne oblike stavb mešane rabe), v spodnji pa so predstavljene stavbe nižje gostote (enodružinske hiše in različne vrste storitvenih objektov). Analiza je pokazala, da je večina parcel razmeroma velika (od 1.200 do $3.500 \mathrm{~m}^{2}$, včasih celo do $9.000 \mathrm{~m}^{2}$ ), kar se ujema z ekstenzivno rabo prostora v predmestijh. Druga značilnost takšnih sistemov je razmeroma nizek delež stavb (večinoma ne zavzemajo več kot $20 \%$ površine parcele). Zato se na teh območjih veliko gradi, stopnja intenzivnosti gradnje je med 0,1 in 0,5. Tovrstna gradnja in urbano tkivo sta značilna za predmestno poljsko krajino, kjer je opazna velika prostorska neurejenost. To je lahko posledica pravnih predpisov, ki urejajo gradnjo na poljskih predmestnih območjih. Pravne podlage za določanje lokacije stavb se zelo razlikujejo celo med sosednjimi območji. To je posledica pokomunistične preobrazbe na Poljskem. Preobrazba na področju prostorskega načrtovanja je potekala v treh fazah (Kolipiński, 2014). Prilagoditvena oziroma pripravljalna faza je potekala v letih 1989-1994, druga faza, v kateri so uvedli in začeli uporabljati nov model, je trajala od leta 1995 do 2003, tretja faza, v kateri se izvajajo popravki sistema, pa še traja. Pravni predpisi glede gradbenih parcel so tem fazam seveda sledili.
Lokacija prvih stavb, zgrajenih takoj po padcu komunizma leta 1989, je bila določena na podlagi prostorskih zakonov in načrtov iz prejšnjega sistema (Izdebski idr., 2007; Dutkowski, 2012; Kolipiński, 2014). Lokalna načrtovalska praksa je temeljila na odločitvah lokalnih občinskih oblasti, ki so prevzele pristojnosti prejšnjih občinskih svetov in še naprej uporabljale prejšnje načrte ne glede na raven njihove kakovosti. Poznejša gradnja v 90. letih 20. stoletja je zajemala predvsem posamične stavbe, katerih lokacija je bila določena na podlagi lokacijskih dovoljenj, ki so se izdajala posamično in večinoma brez upoštevanja nekega splošnega načrta ali vizije (Solarek, 2013). To je samo še povečalo kaotičnost in razpršenost prostorske zgradbe predmestij (Lisowski in Grochowski, 2009). Zadnjih deset let pa skušajo lokalne načrte namenske rabe zemljišč dosledneje uskladiti s prostorskimi dokumenti višjega reda in drugimi, prej sprejetimi načrti namenske rabe prostora (Solarek, 2013). Obstoječo strukturo stavb skušajo uskladiti z načrtovano, kmečki objekti se na primer preurejajo za druge vrste rabe. Vse to je ustvarilo preveliko ponudbo stavbnih zemljǐšc, nastalih s preureditvijo nekdanjih kmečkih zemljišč, in povzročilo še večjo razpršenost grajene strukture (Lisowski in Grochowski, 2009).

Rezultati ankete, opravljene med podjetniki, so potrdili ugotovitve prostorske raziskave. Avtorji so na podlagi prostorske analize iskali odgovore na ta vprašanja:

- Ali gradnjo stavb, v katerih poteka poslovna dejavnost, vedno spremlja tudi stanovanjska gradnja? (da: $80 \%$ )

- Kako pogosto se poslovna dejavnost izvaja v stanovanjski stavbi? (v več kot $55 \%$ primerov)

- Ali so na parceli samo stanovanjske stavbe, $v$ katerih se izvaja poslovna dejavnost (del hiše je preurejen za poslovno dejavnost)? Odgovor je bil pritrdilen v več kot $30 \%$ primerov. Velikost parcel je bila običajno precej manjša kot v drugih primerih in se ni ujemala s povprečno velikostjo stanovanjskega zemljišča, ki znaša približno $800 \mathrm{~m}^{2}$.

V preglednici 4 so predstavljeni izbrani parametri in rezultati analize strukture stavb in pozidave parcel v mestih Hvaščino (Chwaszczyno) in Strašin (Straszyn).

\section{Sklep}

Procesi suburbanizacije, ki potekajo po različnih evropskih državah, niso homogeni, saj na razvoj predmestij v različnih državah vplivajo različni družbeni, gospodarski in prostorski dejavniki. V prostorskem pogledu so za Poljsko značilni pomanjkanje tradicije » učinkovite « rabe zemljǐšc, lokalne prakse in standardov prostorske rabe ter slabosti na področju prostorskega načrtovanja, zlasti na lokalni ravni, ki se kažejo v tem, da se lahko prostorski načrti prosto oblikujejo in zlahka spreminjajo (Fogel, 2012). Prostorska oblika, ki je posledica 
nenačrtnega širjenja poljskih mest, ne upošteva ustreznih urbanističnih standardov prostorske urejenosti. Pogosto se opisuje kot ekspanzivna, nestrukturirana ali kaotična. Eden od razlogov za to bi bila lahko posebna gospodarska značilnost poljskih predmestij: močna navzočnost in dejavnost MSP, katerih število se je v zadnjih 25 letih zelo povečalo (Martyniuk idr., 2016; Martyniuk-Pęczek in Pęczek, v tisku). Zaradi selitve podjetnikov iz mestnih središč so se poljska predmestja spremenila $\mathrm{v}$ podjetniške centre. Na podlagi prejšnjih raziskav, opravljenih na Poljskem, lahko sklepamo, da se podjetniški centri oblikujejo na območjih, kjer je poslovna dejavnost povezana z najnižjimi stroški (poceni zemljišča, najemnine in delovna sila) ali pa zagotavlja veliko povpraševanje. Izsledki, predstavljeni v tem članku, pa kažejo, da bi morale lokalne oblasti in urbanisti, ki želijo urejati in prodajati zemljišča v predmestjih, pozornost posvetiti kakovosti življenjskih razmer, vštevši promet in javni prostor. Ko se posamezniki z močnimi podjetniškimi težnjami odločajo o umestitvi poslovne dejavnosti na predmestno območje, jim je lokacija, ki zagotavlja ustrezne življenjske razmere njihovim družinam, pomembnejša od stroškovnega vidika. To je še zlasti pomembno za umeščanje MSP v predmestja, saj je zaradi bližine osrednjih mest tam zajamčeno dobro povpraševanje. Podjetniki, ki iščjo ustrezno lokacijo za svojo poslovno dejavnost, zato ne izberejo krajev, kjer bi bili poslovni stroški najnižji, ampak tiste, ki lahko zagotovijo nadaljnji razvoj njihovih podjetij in družin. Treba pa je upoštevati, da so pričakovanja v zvezi s kakovostjo (življenjskih razmer in javnega prostora) na Poljskem precej manjša kot v Zahodni Evropi.

Dejstvo, da je bila ta raziskava opravljena v predmestjih samo enega metropolitanskega območja, pomeni določeno omejitev, saj se opisane ugotovitve nanašajo samo na predmestja na metropolitanskem območju mest Gdansk, Gdynia in Sopot. Z raziskavami drugih poljskih metropolitanskih območij bi tako lahko potrdili ali zavrnili trditev, da so pri izbiri predmestne lokacije MSP osebni razlogi pomembnejši od stroškov.

\section{Justyna MARTYNIUK-PĘCZEK}

Gdańsk University of Technology, Faculty of Architecture, Department of Urban and Regional Planning, Gdańsk, Poljska

E-pošta: juspecze@pg.gda.pl

\section{Olga MARTYNIUK}

University of Gdańsk, Faculty of Management, Department of Corporate Finance, Sopot, Poljska

E-pošta: omartyniuk@ug.edu.pl

\section{Anna GIERUSZ}

University of Gdańsk, Faculty of Management, Department of Statistics, Sopot, Poljska

E-pošta: anna.gierusz@ug.edu.pl

\section{Grzegorz PĘCZEK}

Sopot University of Applied Sciences, Faculty of Architecture, Sopot, Poljska

E-pošta: g.peczek@ssw.sopot.pl

\section{Zahvala}

Članek je bil napisan v okviru projekta UMO-2013/09/B/HS4/01175, ki ga je financiral poljski državni znanstveni center.

\section{Opombe}

${ }^{[1]}$ Vojvodstva so razvř̌čena na podlagi skupnega indeksa. Skupni indeks razvoja podjetništva $v$ vojvodstvih je bil oblikovan na podlagi mesta, ki ga je posamezno vojvodstvo zasedlo glede na 26 kategorij spremenljivk, ki se nanašajo na razvoj podjetništva, na primer število podjetij, število zaposlenih v podjetjih, prihodki, stroški in izdatki za naložbe (Cieslik idr., 2014).

${ }^{[2]}$ Meje proučevanega območja so bile določene na podlagi razvojnega načrta Pomorjanskega vojvodstva.

[3] Podatki $z$ dne 31. 12. 2013.

\section{Viri in literatura}

Arauzo-Carod, J. M., in Manjon-Antolin, M. C. (2004): Firm size and geographical aggregation: An empirical appraisal in industrial location. Small Business Economics, 22(3-4), str. 299-312.

DOI: 10.1023/B:SBEJ.0000022216.09083.76

Budner, W. (2004): Location of enterprises. Aspects of economic and spatial and environmental. Poznań, Wydawnictwo Akademii Ekonomicznej w Poznaniu.

Chrzanowska, M., in Drejerska, N. (2015): Małe i średnie przedsiębiorstwa w strefie podmiejskiej Warszawy-określenie znaczenia lokalizacji z wykorzystaniem drzew klasyfikacyjnych. Prace Naukowe Uniwersytetu Ekonomicznego we Wrocławiu, 385, str. 45-52. DOI: $10.15611 / p n .2015 .385 .05$

Cieślik, J., Czarzasty, J., Dąbrowski, J., Koładkiewicz, I., Konieczna-Sałamatin J., Łapiński, J., idr. (2014): Raport o stanie sektora małych i średnich przedsiębiorstw w Polsce w latach 2012 - 2013. Warsaw, Polska Agencja Rozwoju Przedsiębiorczości.

Cohen, N. (2000): Business location decision-making and the cities: Bringing companies back. Washington, DC, Brookings Institution Center on Urban and Metropolitan Policy.

Costa, M. T., Segarra, A., in Viladecans E. (2004): Business dynamics and territorial flexibility. Small Business Economics, 22(3/4), str. 265-281.

Dicken, P., in Lloyd, P. E. (1990): Location in space: Theoretical perspectives in economic geography. New York, Harper \& Row.

Dutkowski, M. (2012): System planowania przestrzennego, Akademie für Raumforschung und Landesplanung (ARL). Dostopno na: https://www. arl-net.de/commin/poland-polska/11-historia-planowania-przestrzennego (sneto 1. 7. 2016)

Flieger, M. (2013): The criteria and barriers to location of business in the process of stimulating the development of the municipalities - empirical results. Research Papers of the Wrocław University of Economics, 284, str. 27-215.

Fogel, P. (2012): Indicators of politics and spatial planning in municipalities. Bulletin PAN KPZK, 250, str. 8-260.

Godlewska, H. (2005): Determinants of location decisions. Varšava, Wyżs za Szkoła Menadżerska.

Godlewska-Majkowska, H. (2016): Powiązania strukturalne a podejmowanie decyzji lokalizacyjnych w małych przedsiębiorstwach. Prace Komisji Geografii Przemysłu Polskiego Towarzystwa Geograficznego, 30(1), str. 47-61. 
Hoover, E. M. (1948): The location of economic activity. New York, McGraw-Hill.

Isard, W. (1956): Location and space-economy. New York, J. Wiley and Sons.

Izdebski, H., Nelicki, A., in Zachariasz, I. (2007): Zagospodarowanie przestrzenne. Polskie prawo na tle standardów demokratycznego państwa prawnego. Varšava, Ernst \& Young.

Karakaya, F., in Canel, C. (1998): Underlying dimensions of business location decisions. Industrial Management and Data Systems, 98(7), str. 321-29. DOI: 10.1108/02635579810205395

Kimelberg, S. M., in Williams, E. (2013): Evaluating the importance of business location factors: The influence of facility type. Growth and Change, 44(1), str. 92-117. DOI: 10.1111/grow.12003

Kolipiński, B. (2014): Planowanie przestrzenne w Polsce w minionym 25-leciu. MAZOWSZE Studia Regionalne, 2014(15), str. 109-118.

Kupke, V., in Pearce, J. (2000): Identifying industrial location and site preferences for small business. Pacific Rim Property Research Journal, 6(1), str. 12-23. DOI: 10.1080/14445921.2000.11104080

Leśniewski, M. A. (2012): Factors location of the enterprises - empirical results. Studia i Prace Kolegium Zarzadzania, 113, str. 117-133.

Liang, C. L. K., Su, Y. T., Dunn, P., in Halbrendt, C. (2001): A nonparametric approach to study key factors influencing location decisions for small manufacturing enterprises in Vermont. Prispevek je bil predstavljen na konferenci z naslovom Second Annual USASBE/SBIDA Joint National Conference, ki je potekala od 7. do 10. februarja v Orlandu na Floridi. Tipkopis.

Lisowski, A., in Grochowski, M. (2009): Procesy suburbanizacji. Uwarunkowania. Formy i konsekwencje. Ekspertyzy do Koncepcji Zagospodarowania Przestrzennego Kraju, Tom 1 (2009), Warsaw, Ministerstwo Rozwoju Regionalnego, str. 217-281.

Lopez, R. A., in Henderson, N. R. (1989): The determinants of location choices for food processing plants. Agribusiness, 5(6), str. 619-632. DOI: $10.1002 /$

1520-6297(198911)5:6<619::AID-AGR2720050607>3.0.CO;2-A

Lösch, A. (1940): Die räumliche Ordnung der Wirtschaft. Jena, Gustav Fischer.

Martyniuk, O., Martyniuk-Pęczek, J., in Pęczek, G. (2016): Economic vitality of Polish suburbs. GSTF Journal of Engineering Technology (JET), 3(4), str. 39-48.

Martyniuk-Pęczek, J., in Pęczek, G. ( $v$ tisku) Spatial structure of the suburban zones in selected entrepreneurship nests of the Tricity metropolitan area. Keeping Up with Technologies to Make Cognitive City. Newcastle upon Tyne, Cambridge Scholars Publishing.

Mazzarol, T., in Choo, S. (2003): A study of the factors influencing the operating location decisions of small firms. Property Management, 21(2), str. 190-208. DOI: 10.1108/02637470310478918

Michelacci, C., in Silva, O. (2007): Why so many local entrepreneurs? The Review of Economics and Statistics, 89(4), str. 615-633. DOI: $10.1162 /$ rest.89.4.615

Moore, B., Tyler, P., in Elliott, D. (1991): The influence of regional development incentives and infrastructure on the location of small and medium sized companies in Europe. Urban Studies, 28(6), str. 1001-1026. DOI: 10.1080/00420989120081171

Palander, T. (1935): Beiträge zur Standortstheorie. Uppsala, Almqvist \& Wiksell.
Poniatowska-Jaksch, M. (1997): Wpływ czynników lokalizacyjnych na wzrost aktywności gospodarczej w strefie podmiejskiej Warszawy w świetle badań ankietowych. Monografie i Opracowania/Szkoła Główna Handlowa, 411, str. 134-166.

Porter, M. E. (2000); Location, competition, and economic development: Local clusters in a global economy. Economic Development Quarterly, 14(1), str. 15-34. DOl: 10.1177/089124240001400105

Prat, J. C. R.-S., in Marcén, R. F. (2006): Influential factors in location choice of Spanish businesses in Aragon. Journal of Entrepreneurship, 15(1), str. 63-81. DOI: 10.1177/097135570501500105

Pred, A. R. (1967): Behaviour and location: Foundations for a geographic dynamic location theory. Part 1. Studies in Geography, Series B. 27. Lund, University Lund.

Predöhl, A. (1928): The theory of location in its relation to general economics. Journal of Political Economy, 36(3), str. 371-390. DOI: 10.1086/253950

Risselada, A. H., in Schutjens V. (2012): Firm location behaviour in the new economy: Understanding the role of property factors in location decisions of neighbourhood firms. Prispevek je bil predstavljen na konferenci z naslovom Third ECFED International Workshop, ki je potekala od 14. do 15. junija v Namurju v Belgiji. Tipkopis.

Solarek, K. (2013): Struktura przestrzenna strefy podmiejskiej Warszawy. Determinanty współczesnych przekształceń. Varšava, Oficyna Wydawnicza Politechniki Warszawskiej.

Sullivan, P., Halbrendt, C., in Buescher, M. (1998): Small business location considerations for agriculture and forestry sectors. Prispevek je bil predstavljen na konferenci z naslovom International Council for Small Businesses $43^{\text {rd }}$ World Conference, ki je potekala od 8. do 10. junija v Singapurju. Tipkopis.

Vaillant, Y., Lafuente, E., in Serarols, C. (2012): Location decisions of new 'knowledge intensive service activity' firms: the rural-urban divide. The Service Industries Journal, 32(16), str. 2543-2563. DOI: 10.1080/02642069.2011.594880

Van Dijk, J., in Pellenbarg, P. (2000): Firm relocation decisions in the Netherlands: An ordered logit approach. Regional Science, 79(2), str. 191-219. DOI: 10.1007/s101100050043

Van Noort, E. A., in Reijmer, I. A. (1999): Location choice of SMEs: The most important determinants. Zoetermeer, EIM Small Business Research and Consultancy.

Vlachou, C., in lakovidou, O. (2015): The evolution of studies on business location factors. Journal of Developmental Entrepreneurship, 20(4), str. 1-23. DOI: 10.1142/S1084946715500235

Von Thünen, J. H. (1875): Der isolierte Staat in Beziehung auf Landwirtschaft und Nationalökonomie (Vol. 1). Wiegant, Hempel \& Parey. DOI: 10.5962/bhl.title.24798

Weber, A. (1929): Theory of the location of industries. Prev. C. J. Friedrich. Chicago, University of Chicago Press. Dostopno na: https://archive.org/ details/alfredweberstheo00webe (sneto 6. 7. 2016).

Yu, L., in Artz, G. (2009): Migration and rural entrepreneurship, Working paper no. 09017. Ames, lowa State University. Dostopno na: http://lib.dr.iastate.edu/econ_las_workingpapers/142/ (sneto 10. 7. 2016). 